\title{
Antibacterial, antifungal and antioxidant activities of whole plant chemical constituents of Rumex abyssinicus
}

Irene Chinda Kengne ${ }^{1}$, Léonel Donald Tsamo Feugap², Abdel Jélil Njouendou ${ }^{3}$ Claudia Darille Jouogo Ngnokam², Mahamat Djamalladine Djamalladine ${ }^{2}$, David Ngnokam², Laurence Voutquenne-Nazabadioko ${ }^{4}$ and Jean-De-Dieu Tamokou ${ }^{1 *}$ (D)

\begin{abstract}
Background: Antibiotic resistance has contributed to the burden of infectious diseases both in the hospital and community setting, and represents a great threat to public health. Previous studies have revealed the role of reactive oxygen species as intermediate mediators of tissue damage, following antibiotherapies, indicating the need of associating antioxidants to these treatments. Therefore, the present work was designed to study the antibacterial, antifungal and antioxidant activities of extracts and compounds from Rumex abyssinicus Jacq. (Polygonaceae), as well as to investigate the antibacterial mechanisms of action of the most effective agents.

Methods: The plant extracts were prepared by maceration in organic solvents followed by column chromatography of the EtOAc fraction and purification of different fractions which led to the isolation and characterization of pure compounds. The antimicrobial activities of the extracts/compounds and their combinations with ciprofloxacin and fluconazole were evaluated using the broth microdilution method by determining the minimum inhibitory concentration (MIC) and minimum microbicidal concentration (MMC). The effects of the extracts on the bacterial cell membrane and microbial respiratory chain dehydrogenase enzyme activity were determined by spectrophotometric methods. Antioxidant activity was evaluated using 1,1-diphenyl-2-picrylhydrazyl (DPPH) and gallic acid equivalent antioxidant capacity (GAEAC) assays.
\end{abstract}

Results: Chrysophanol (1), physcion (2), Ergosta-6,22-diene-3,5,8-triol (3), emodin (4), 6-hydroxyemodin (citreorosein) (5), chrysophanein (6) and physcionin (7) were isolated from EtOAc fraction of $R$. abyssinicus and displayed different degrees of antimicrobial activities (MIC $=8-256 \mu \mathrm{g} / \mathrm{mL}$ ). The $\mathrm{MeOH}$ extract and compounds 2 and 4 exhibited synergistic effects with ciprofloxacin and fluconazole. Compounds 1, 2 and the combined mixture of $6+7$ displayed the highest antioxidant activity (GAEAC $=83.38-106.03 \mu \mathrm{g} / \mathrm{mL})$.

\footnotetext{
*Correspondence: jtamokou@yahoo.fr; jean.tamokou@univ-dschang.org

'Department of Biochemistry, Research Unit of Microbiology and

Antimicrobial Substances, Faculty of Science, University of Dschang, P.O. Box

67, Dschang, Cameroon

Full list of author information is available at the end of the article
}

(C) The Author(s). 2021 Open Access This article is licensed under a Creative Commons Attribution 4.0 International License, which permits use, sharing, adaptation, distribution and reproduction in any medium or format, as long as you give appropriate credit to the original author(s) and the source, provide a link to the Creative Commons licence, and indicate if changes were made. The images or other third party material in this article are included in the article's Creative Commons licence, unless indicated otherwise in a credit line to the material. If material is not included in the article's Creative Commons licence and your intended use is not permitted by statutory regulation or exceeds the permitted use, you will need to obtain permission directly from the copyright holder. To view a copy of this licence, visit http://creativecommons.org/licenses/by/4.0/ The Creative Commons Public Domain Dedication waiver (http://creativecommons.org/publicdomain/zero/1.0/) applies to the data made available in this article, unless otherwise stated in a credit line to the data. 
Conclusion: $R$. abyssinicus is a potential source of antibacterial, antifungal and antioxidant agents. The antibacterial mechanisms of action of the $\mathrm{MeOH}$ extract and compound 2 are due to disruption of the cytoplasmic membrane and inhibition of the microbial respiratory chain dehydrogenase enzyme activity. To the best of our knowledge, this is the first report of test samples and ciprofloxacin / fluconazole association against MDR strains. The observed activity of the isolated compounds against bacteria and fungi including MDR strains deserves further exploration.

Keywords: Rumex abyssinicus, Antimicrobial, Antioxidant, Multiresistant strains, Membrane leakage, Dehydrogenase activity

\section{Background}

The increasing appearance of resistant pathogenic bacteria and fungi to synthetic antimicrobial agents represents an alarming threat to public health. The most commonly encountered antibiotic-resistant bacteria, methicillin-resistant S. aureus (MRSA), vancomycinresistant Enterococci (VRE), and penicillin and cephalosporin-resistant Streptococci (PCRS) have contributed to the burden of infectious diseases both in the hospital and community setting [1]. Majority of the classical antibiotics today sold in the market have major disadvantages resulting from the side effects on patients and the developed multiple drug resistances by the pathogenic microorganisms [2]. Hence, a growing interest in the discovery of new natural antimicrobial agents has been observed, with the objective to combat these resistant pathogens while avoiding or minimizing the undesirable consequences and side effects related to the consumption of synthetic antibiotics [3]. Previous studies have demonstrated detrimental side effects of bactericidal antibiotics such as quinolones, aminoglycosides while, $\beta$-lactams caused mitochondrial dysfunction and reactive oxygen species (ROS) overproduction in mammalian cells, leading to oxidative damage to DNA, proteins, and membrane lipids [4]. Therefore, associating antioxidant with antibiotic therapy seems to be a strategy to mitigate or prevent side effects.

Reactive oxygen species are oxygen-derived free radicals, metabolic products arising from endoplasmic reticulum and mitochondria of various cells. Free radicals which are delivered as a consequence of typical biochemical responses in the body are implicated in diabetes, atherosclerosis, ageing, cancer, inflammation, immunosuppression, neurodegenerative disorders and ischemic heart disease [5]. Free radicals are proven to be highly toxic to pathogens and they are used as a means to prevent tissue colonisation by the microorganisms. Thus, the production of free radicals is highly elevated during infection and this situation can cause oxidative stress; which further complicates the patient's condition. Secondary metabolites of plants such as flavonoids and terpenoids play an important role in the defense against free radicals and pathogenic microorganisms [6]. Previous studies have shown that the use of plant-derived medicines have increased tremendous interest in the search of alternative antimicrobial and antioxidant agents because of the perception that they cause minimal adverse effects and have a long history of use in folk medicine for the treatment of infectious diseases and oxidative stress conditions $[7,8]$. However, the combination of antioxidant and antimicrobial agents has gained wide acceptance within the pharmaceutical industries [9]. In fact, combining two or more compounds could be more effective for the improvement of antioxidant and antimicrobial activities and could offer a synergistic effect. The fact that flavonoids, terpenoids and saponins can improve the susceptibility of some bacteria to certain antibiotics have been demonstrated in many studies [10, 11]. Natural products of higher plants may possess a new source of antimicrobial and antioxidant agents with possibly novel mechanisms of action [12]. Hence, three levels of interactions are involved: interaction with the outer cellular components; interaction with the cytoplasmic membrane and interaction with cytoplasmic constituents. Natural products can act with the bacterial cells at one level or all three levels of interaction to produce their antimicrobial activities. Their systematic and methodical screening may result in the discovery of novel active principles to overcome resistance mechanisms in multidrug resistant microorganisms.

It is well documented that plants belonging to Rumex genus possess suitable medicinal properties, which are based mainly on the presence of anthraquinones, flavonoids and terpenoids [13]. R. abyssinicus Jacq. (Family: Polygonaceae) commonly known as Spinach Rhubarb, is a large herbaceous perennial plant that grows up to $4 \mathrm{~m}$ in height. This plant is mainly found in tropical Africa especially in the drier areas. $R$. abyssinicus is locally used as astringent, purgative, taeniafuge, depurative and hemostatic [14]. The plant is also used in the management of breast cancer, gonorrhea, liver diseases, hypertension and hemorrhoids [14]. The fresh or dried plant is applied externally to treat cough, pneumonia, wounds, rheumatism, sores and scabies [14]. An extract of rhizome is consumed to control mild forms of diabetes and, with water, to cure stomach-ache [14]. The crude extracts of $R$. abyssinicus have been shown to possess antibacterial [15, 16], anticancer [16], antiviral [15], anti- 
inflammatory [15, 17], antioxidant [18], wound healing [17], antimalarial [19], diuretic and analgesic [20] activities. Up to date, there has been no report on the antibacterial, antifungal and antioxidant activities of compounds isolated from $R$. abyssinicus, although there is an ample ethnobotanical claim for these properties. Therefore, the present work was designed to study the antibacterial, antifungal and antioxidant activities of extracts and compounds from $R$. abyssinicus as well as to investigate the mechanisms of antibacterial activity of the most effective agents. Interactions of the methanol extract/compounds from $R$. abyssinicus and antibiotics against bacterial and yeast species were also investigated.

\section{Methods}

General experimental procedures

NMR analysis

The ${ }^{1} \mathrm{H}$ and ${ }^{13} \mathrm{C}$-NMR spectra were recorded on a Bruker Avance III 600 spectrometer equipped with a cryoplatform $\left({ }^{1} \mathrm{H}\right.$ at $600 \mathrm{MHz}$ and ${ }^{13} \mathrm{C}$ at $\left.150 \mathrm{MHz}\right)$. 2D NMR experiments were performed using standard Bruker microprograms (Xwin-NMR version 2.1 software). All chemical shifts $(\delta)$ are reported in parts per million (ppm) with the solvent signal as reference relative to TMS $(\delta=0)$ as internal standard, while the coupling constants $(J)$ are given in Hertz $(\mathrm{Hz})$. Deuterated solvents, methanol $\left(\mathrm{CD}_{3} \mathrm{OD}\right)$, dimethyl sulfoxide (DMSO$\left.d_{6}\right)$, and chloroform $\left(\mathrm{CDCl}_{3}\right)$ were used as solvents for the NMR experiments.

\section{Chromatographic methods}

Column chromatography was run on Merck silica gel (VWR, France) 60 (70-230 mesh) and gel permeation on Sephadex LH-20 (VWR, France), while TLC was carried out on silica gel GF254 pre-coated plates and the spots were visualized by an UV lamp multiband UV254/365 nm (ModelUVGL-58 Upland CA 91786, U.S.A) followed by spraying with $50 \% \mathrm{H}_{2} \mathrm{SO}_{4}$ and then heating at $100{ }^{\circ} \mathrm{C}$.

\section{Sample collection}

The whole plant of Rumex abyssinicus Jacq. was collected in February 2018 from the wild in Dschang, western region of Cameroon. The botanical identification was carried out by Victor Nana, a botanist of the National Herbarium of Cameroon, where a voucher specimen ( $\left.\mathrm{N}^{\circ} 50,551 / \mathrm{HNC}\right)$ has been deposited.

For the collection of plants, no specific permits were required for the described field studies. For any locations/activities, no specific permissions were required. All locations of plant collection were not privatelyowned or protected in any way and the field studies did not involve endangered or protected species.

\section{Extraction and fractionation}

The whole plant material of $R$. abyssinicus was air-dried at room temperature and ground into fine powder. This dried powder $(4.5 \mathrm{~kg})$ was extracted at room temperature with methanol $(3 \times 20 \mathrm{~L}, 72 \mathrm{~h})$ to yield $200 \mathrm{~g}$ of crude methanol extract after evaporation of solvent under reduced pressure. A part of this crude extract $(195 \mathrm{~g})$ underwent a differential solubilization with $\mathrm{H}_{2} \mathrm{O}$ /EtOAc ( $300 \mathrm{~mL} / 500 \mathrm{~mL}$ ) followed by $\mathrm{H}_{2} \mathrm{O} / n-\mathrm{BuOH}(300 \mathrm{~mL} /$ $500 \mathrm{~mL}$ ). After evaporation of each solvent under reduced pressure, we obtained $50 \mathrm{~g}$ of EtOAc and $18 \mathrm{~g}$ of $n-\mathrm{BuOH}$ extracts respectively.

\section{Isolation of compounds}

A part of the EtOAc fraction of $R$. abyssinicus $(45 \mathrm{~g})$ was subjected to silica gel column chromatography eluted with $n$-hexane-EtOAc $(95: 5 \rightarrow 80: 20) \quad$ followed by EtOAc- $\mathrm{MeOH}(95: 5 \rightarrow 70: 30)$ gradient graduated elution to yield seventy fractions of $400 \mathrm{~mL}$ each. These were combined on the basis of TLC profiles to yield eight major fractions A-H (A: 1-3; B: 4-10; C: 11-22; D: 2328; E: 29-35; F: 36-44; G: 45-63; H: 64-70). Fraction A $(4.0 \mathrm{~g})$ underwent column chromatography on silica gel with the $n$-hexane-EtOAc system (95:5) to yield compounds $1(15 \mathrm{mg})$ [21] and 2 (17 mg) [22]. Sephadex LH20 gel column chromatography of fraction $\mathrm{C}(1.9 \mathrm{~g})$ led to two sub-fractions $\left(C_{1}\right.$ and $\left.C_{2}\right)$. Purification of subfraction $\mathrm{C}_{1}(500 \mathrm{mg})$ by silica gel column chromatography ( $n$-hexane-EtOAc, $90: 10 \rightarrow 80: 20$ ) resulted in compound $3(15 \mathrm{mg})$ [23]. The sub-fraction $C_{2}(300 \mathrm{mg})$, was purified on Sephadex LH-20 gel column using $\mathrm{MeOH}$ as eluent to give compound 4 (40 mg) [22]. After Sephadex LH-20 gel column using $\mathrm{MeOH}$, fraction $\mathrm{D}$ (3.74 g) led to three sub-fractions $D_{1}, D_{2}$ and $D_{3}$. Purification of $D_{3}$ ( $400 \mathrm{mg}$ ) sub-fraction by silica gel column chromatography with $n$-hexane-EtOAc (85:15) gave compound $\mathbf{5}$ $(11 \mathrm{mg})$ [24]. Recrystallization of fraction G (5 g) afforded a mixture of two compounds $6+7(10 \mathrm{mg})$ [25] which unfortunately, was not separated by silica gel column chromatography method.

\section{Antimicrobial assay \\ Microorganisms}

Five bacteria and two yeasts were tested for their susceptibility to the studied samples. The studied microorganisms were three Gram-positive (Staphylococcus aureus ATCC25923, methicillin sensitive S. aureus MSSA01 and methicillin resistant $S$. aureus MRSA03) and two Gram-negative (Pseudomonas aeruginosa ATCC27853, Shigella flexneri SDINT) bacteria and two yeast strains of Candida albicans ATCC10231 and Cryptococcus neoformans H99. These microorganisms were taken from our laboratory collection. The bacterial and fungal species were maintained on agar slant at $+4{ }^{\circ} \mathrm{C}$ and on 
nutrient agar (NA, Conda, Madrid, Spain) and Sabouraud Dextrose Agar (SDA, Conda) slants respectively, prior to any antimicrobial test.

Determination of minimum inhibitory concentration (MIC) and minimum microbicidal concentration (MMC)

MIC and MMC values were determined as described earlier [26]. The test samples were dissolved in dimethylsulfoxide (DMSO). The negative control well consisted of $195 \mu \mathrm{L}$ of $\mathrm{MHB}$ or SDB and $5 \mu \mathrm{L}$ of the standard inoculum. The MICs were visually assessed and were considered as the lowest sample concentration inhibiting the growth of the microorganism. The lowest concentrations that showed no visual growth after the subculturing were considered as the minimum microbial concentration (MMCs). Ciprofloxacin (Sigma-Aldrich, Steinheim, Germany) and fluconazole (Merck, Darmstadt, Germany) were used as positive controls for bacteria and yeasts, respectively. All tests were performed in triplicate.

\section{Combined effect of antibiotics and $\mathrm{MeOH}$ extract, compounds 2 or 4}

The antimicrobial effects of a combination of samples ( $\mathrm{MeOH}$ extract, compounds 2 and 4 ), which exhibited the highest antimicrobial activities, and antibiotics (ciprofloxacin and fluconazole) were assessed by the checkerboard method as previously described [27]. The inoculum was initially prepared as described above. The test microorganisms were inoculated into a 96-well microtitre plates and a serial dilution of two antimicrobial agents: antibiotic and $\mathrm{MeOH}$ extract, compound $\mathbf{2}$ or $\mathbf{4}$. Each well consisted of unique combination of test sample and antibiotic concentrations. The plates were then incubated for $24 \mathrm{~h}$ at $37^{\circ} \mathrm{C}$. The analyses were performed in triplicates. And the antimicrobial agents interactions were evaluated by calculating the fractional inhibitory concentration (FIC) indices. The FIC is defined as follows: MIC of antibiotic tested in combination/MIC of antibiotic tested alone + MIC of extract/compound tested in combination/MIC of extract/compound tested alone. The FIC index is interpreted as FIC $\leq 0.5$ : synergistic effect, $0.5<$ FIC $\leq 1$ : additive effect, $1<$ FIC $\leq 2$ : indifferent effect, and FIC > 2.0: antagonistic effect.

\section{Antibacterial mechanism studies Cell membrane leakage assay}

The alteration of cell membrane of $P$. aeruginosa and S. flexneri was evaluated by measuring the optical densities at $260 \mathrm{~nm}$ and $280 \mathrm{~nm}$ of the bacterial suspensions in the presence and absence of $\mathrm{MeOH}$ extract and compound 2 using the method described by Karsha and Lakshmi [28].

\section{Evaluation of the sugar leakage through membrane of bacteria}

$10 \mathrm{~mL}$ of the bacterial suspension containing $10^{8} \mathrm{CFU} /$ $\mathrm{mL}$ were inoculated into $\mathrm{MeOH}$ extract or compound 2 at $1 / 2 \mathrm{MIC}$, MIC and $2 \mathrm{MIC}$ and incubated at $37^{\circ} \mathrm{C}$ under agitation at $150 \mathrm{rpm}$ for $12 \mathrm{~h}$. After incubation, the mixture was centrifuged at $12,000 \mathrm{rpm}$ and the supernatant was collected. The concentration of reducing sugar was determined spectrophotometrically at $550 \mathrm{~nm}$ using 3-5 dinitro-salicylic acid (DNS) [29].

\section{Assay of respiratory chain dehydrogenase enzyme activity in the bacteria}

Cellular bioenergetic is a domain with promising future in the development of novel antimicrobials. Several studies have evaluated the bioenergetics of various bacterial pathogens, which explain the abilities of electron donor and acceptor utilisation, and the regulation of components of electron transport chain in bacteria. In this assay, the effect of the most effective agents on respiratory chain dehydrogenase enzyme activity of pathogenic bacteria as a test for mechanism of antibacterial action was performed. The dehydrogenase activity assay was performed using 2,3,5- triphenyl tetrazolium chloride (TTC) as previously described [30]. The TTC serves as the artificial electron acceptor and is reduced to red coloured triphenyl formazan (TPF). The assay was carried out with $3 \mathrm{ml}$ of nutrient broth-glucose-TTC medium, supplemented with varying concentrations of $\mathrm{MeOH}$ extract or compound 2 in $20 \mathrm{~mL}$ screw-capped test tubes. The TPF produced after each exposure period $(0,30,60 \mathrm{~min})$ was extracted in $4 \mathrm{~mL}$ of amyl alcohol and determined spectrophotometrically at $500 \mathrm{~nm}$. The amount of formazan produced was determined from a standard dose-response curve $\left(\mathrm{R}^{2}=0.9983\right)$. Dehydrogenase activity was expressed as the amount of TPF formed $(\mu \mathrm{g})$ per amount of dry cell weight of cell biomass (in $\mathrm{mg}$ ). Data were expressed as the mean \pm standard deviation.

\section{Antioxidant assay \\ Gallic acid equivalent antioxidant capacity (GEAC) assay}

The GEAC test was done as previously described [31] with slight modifications. In a quartz cuvette, to $950 \mu \mathrm{L}$ acetate buffer $(\mathrm{pH}=5.0,100 \mathrm{mM})$, the following were added: $20 \mu \mathrm{L}$ laccase ( $1 \mathrm{mM}$ stock solution), $20 \mu \mathrm{L}$ test sample, $10 \mu \mathrm{L}$ ABTS (2,2'-azinobis(3-ethylbenzothiazoline-6-sulfonic acid) (74 $\mathrm{mM}$ stock solution). The purification of laccase from Sclerotinia sclerotiorum was done according to the protocol described [32]. The sample concentrations in the assay mixture were $800,400,200$, $100,10 \mu \mathrm{g} / \mathrm{mL}$ for the extracts and $200,100,50,25,12.5$, $6.25,3.125,1.56 \mu \mathrm{g} / \mathrm{mL}$ for the isolated compounds. The content of the generated $\mathrm{ABTS}^{\bullet+}$ radical was measured 
at $420 \mathrm{~nm}$ after $240 \mathrm{~s}$ reaction time and was converted to gallic acid equivalents by the use of a calibration curve (Pearson's correlation coefficient: $r=0.997$ ) constructed with $0,4,10,14,28,56,84 \mu \mathrm{M}$ gallic acid standards rather than Trolox. Experiments were done in triplicate.

\section{Diphenyl-1-picrylhydrazyl (DPPH) free radical scavenging assay}

The free radical scavenging activity of extracts and compounds was evaluated according to described methods [33]. The $\mathrm{EC}_{50}(\mu \mathrm{g} / \mathrm{ml})$, which is the amount of sample necessary to inhibit by $50 \%$ the absorbance of free radical DPPH was calculated [33]. Vitamin C was used as a standard control. All the analyses were carried out in triplicate.

\section{Cytotoxicity assay}

Three male Wistar rats (Rattus novergicus), aged 10-12 weeks and weighing 230 to $240 \mathrm{~g}$ were used. These animals were bred in the animal house of the University of Dschang, Cameroon. Efforts were also made to minimize animal suffering and to reduce the number of animal used in the experiment. All the rats were anaesthesized via intraperitoneal injection of the mixture of ketamine (50 $\mathrm{mg} / \mathrm{kg}$ body weight, BW) and xylazine $(10 \mathrm{mg} / \mathrm{kg}$ $\mathrm{BW}$ ), in a dose that is commonly used for operation purposes. Subsequently the unconscious animals were decapitated swiftly and the whole blood $(10 \mathrm{~mL})$ was collected by cardiac puncture into a conical tube containing Ethylene Diamine Tetra Acetic Acid (EDTA) as an anticoagulant. Erythrocytes were obtained by centrifugation at room temperature for $10 \mathrm{~min}$ at $1000 \mathrm{x} g$ and were washed three times in PBS buffer [34]. The cytotoxicity was evaluated as previously described [34].

\section{Statistical analysis}

Data were analyzed by one-way analysis of variance followed by Waller-Duncan Post Hoc test. The experimental results were expressed as the mean \pm Standard Deviation (SD). Differences between groups were considered significant when $p<0.05$. All analyses were performed using the Statistical Package for Social Sciences (SPSS, version 12.0) software.

\section{Results}

\section{Chemical composition}

A total of five pure compounds ( 1 to 5 ) and one mixture of two compounds (6 and 7) were isolated from $R$. abyssinicus. Based on their spectral data $(1 \mathrm{H}$ and $13 \mathrm{C} \mathrm{NMR}$, $1 \mathrm{H}-1 \mathrm{H}$ COSY, HSQC, HMBC, and ROESY), their chemical structures as illustrated in Fig. 1 were identified as follows: 1: Chrysophanol; 2: Physcion; 3: Ergosta-6,22diene-3,5,8-triol; 4: Emodin; 5: 6-hydroxyemodin (Citreorosein); 6: Chrysophanein; 7: Physcionin.<smiles>Cc1cc(O)c2c(c1)C(=O)c1cccc(O)c1C2=O</smiles>

1<smiles>COc1cc(O)c2c(c1)C(=O)c1cc(C)cc(O)c1C2=O</smiles>

2<smiles>Cc1cc(O)c2c(c1)C(=O)c1cc(O)cc(O)c1C2=O</smiles><smiles>CC(C)[C@H](C)/C=C/[C@H](C)C1CCC2C3(C)CCC4(O)C(CCC3C12O)C1(C)CC(O)CCC14C</smiles><smiles>O=C1c2cc(CO)cc(O)c2C(=O)c2cc(O)cc(O)c21</smiles>

5<smiles>COc1cc(OC2OC(CO)C(O)C(O)C(O)C2O)c2c(c1)C(=O)c1cc(C)cc(O)c1C2=O</smiles>

Fig. 1 Chemical structures of compounds isolated from R. abyssinicus (1-7): 1: Chrysophanol; 2: Physcion; 3: Ergosta-6,22-diene-3,5,8-triol; 4: Emodine; 5: 6-hydroxyemodin (Citreorosein; 6: Chrysophanein; 7: Physcionin 
Compounds 1, 2 and 3 were derived from the EtOAc fraction while the remaining were isolated from the methanolic extract.

\section{Chrysophanol (1)}

Yellow powder; $\left(\mathrm{C}_{15} \mathrm{H}_{10} \mathrm{O}_{4}\right)$; ${ }^{1} \mathrm{H}-\mathrm{NMR}\left(600 \mathrm{MHz}, \mathrm{CDCl}_{3}\right)$ $\delta: 12.08(s, 1-\mathrm{OH}), 11.97(s, 8-\mathrm{OH}) 7.84(d, 7.5 \mathrm{~Hz}, \mathrm{H}-5)$, 7.77 (br s, H-6), 7.69 (br s, H-4), $7.30(d, 8.4 \mathrm{~Hz}, \mathrm{H}-7)$, $7.12($ br s, $\mathrm{H}-2), 2.48\left(s,-\mathrm{CH}_{3}\right) ;{ }^{13} \mathrm{C}-\mathrm{NMR}(150 \mathrm{MHz}$, $\left.\mathrm{CDCl}_{3}\right)$ 8: 192.5 (C-9), 182.1 (C-10), 162.7 (C-1), 162.4 (C-8), 149.3 (C-3), 137.0 (C-6), 133.6 (C-11), 133.2 (C14), 124.5 (C-7), 124.3 (C-2), 121.3 (C-4), 119.9 (C-5), 115.8 (C-12), 113.7 (C-13), $22.4\left(-\mathrm{CH}_{3}\right)$.

\section{Physcion (2)}

Yellow powder; $\left(\mathrm{C}_{16} \mathrm{H}_{12} \mathrm{O}_{5}\right) ;{ }^{1} \mathrm{H}-\mathrm{NMR}\left(600 \mathrm{MHz}, \mathrm{CDCl}_{3}\right)$ $\delta: 12.34(s, 1-\mathrm{OH}), 12.15(s, 8-\mathrm{OH}), 7.65$ (br s, H-5), 7.39 (d, $2.5 \mathrm{~Hz}, \mathrm{H}-4), 7.10$ (br s, H-7), 6.70 (d, $2.5 \mathrm{~Hz}, \mathrm{H}-2)$, $3.95\left(s, \mathrm{OCH}_{3}\right), 2.46\left(s,-\mathrm{CH}_{3}\right) ;{ }^{13} \mathrm{C}-\mathrm{NMR}(150 \mathrm{MHz}$, $\mathrm{CDCl}_{3}$ ) $\delta: 190.8$ (C-9), 182.1 (C-10), 166.6 (C-3), 165.2 (C-1), 162.5 (C-8), 148.5 (C-6), 135.2 (C-14), 133.2 (C11), 124.6 (C-7), 121.4 (C-5), 113.7 (C-12), 110.3 (C-13), $108.3(\mathrm{C}-4), 106.8(\mathrm{C}-2), 56.1\left(-\mathrm{OCH}_{3}\right), 22.2\left(-\mathrm{CH}_{3}\right)$.

\section{Ergosta-6,22-diene-3,5,8-triol (3)}

White powder; $\left(\mathrm{C}_{28} \mathrm{H}_{46} \mathrm{O}_{3}\right) ;{ }^{13} \mathrm{C}-\mathrm{NMR} \quad(150 \mathrm{MHz}$, $\mathrm{CDCl}_{3}$ ): $\delta 135.5$ (C-6), 135.3 (C-22), 132.4 (C-23), 130.9 (C-7), 82.3 (C-5), 79.6 (C-8), 66.6 (C-3), 56.3 (C-17), 51.8 (C-14), 51.2 (C-9), 44.7 (C-13), 42.9 (C-24), 39.9 (C-20), 39.4 (C-11), 37.1 (C-10), 37.0 (C-4), 34.8 (C-1), 33.2 (C25), 30.2 (C-2), 28.8 (C-15) 23.5 (C-12), 21.0 (C-21), 20.8 (C-16), 20.1 (C-26), 19.8 (C-28), 18.3 (C-19), 17.7 (C-27), 13.0 (C-18).

\section{Emodin (4)}

Red powder; $\left(\mathrm{C}_{15} \mathrm{H}_{10} \mathrm{O}_{5}\right)$; ${ }^{1} \mathrm{H}-\mathrm{NMR}(600 \mathrm{MHz}, \mathrm{DMSO}-$ $\left.d_{6}\right) \delta: 12.1(s, 3-\mathrm{OH}), 12.0(s, 8-\mathrm{OH}) 7.48(d, 0.7 \mathrm{~Hz}, \mathrm{H}-$ 5), $7.16(d, 0.7 \mathrm{~Hz}, \mathrm{H}-7) 7.11(d, 2.4 \mathrm{~Hz}, \mathrm{H}-4) 6.59$ (d, 2.4 $\mathrm{Hz}, \mathrm{H}-2), 2.41\left(s,-\mathrm{CH}_{3}\right) ;{ }^{13} \mathrm{C}-\mathrm{NMR}(150 \mathrm{MHz}, \mathrm{DMSO}-$ $\left.d_{6}\right) \delta: 190.2$ (C-9), 181.9 (C-10), 166.1 (C-1), 164.9 (C-3), 161.9 (C-8), 148.7 (C-6), 135.6 (C-14), 133.3 (C-11), 124.6 (C-7), 120.9 (C-5), 113.8 (C-12), 109.4 (C-13), 109.3 (C-4), 108.4 (C-2), $21.9\left(-\mathrm{CH}_{3}\right)$.

\section{Citreorosein (5)}

Red powder; $\left(\mathrm{C}_{15} \mathrm{H}_{10} \mathrm{O}_{6}\right) ;{ }^{1} \mathrm{H}-\mathrm{NMR}\left(600 \mathrm{MHz}, \mathrm{CD}_{3} \mathrm{OD}\right)$ $\delta: 7.28$ (br s, H-2), 7.75 (br s, H-4), 7.20 (br s, H-5), 6.54 (br s, H-7), $4.70\left(s,-\mathrm{OCH}_{2^{-}}\right) ;{ }^{13} \mathrm{C}-\mathrm{NMR} \quad(150 \mathrm{MHz}$, $\left.\mathrm{CD}_{3} \mathrm{OD}\right)$ 8: 191.5 (C-9), 183.4 (C-10), 169.1 (C-8), 166.7 (C-6), 163.7 (C-1), 152.9 (C-3), 136.9 (C-11), 135.0 (C14), 122.2 (C-2), 118.4 (C-4), 115.9 (C-13), 111.1 (C-5), 109.2 (C-7), 108.5 (C-12), $64.1\left(-\mathrm{OCH}_{2}{ }^{-}\right)$.

\section{Chrysophanein (6)}

Yellow powder; $\left(\mathrm{C}_{21} \mathrm{H}_{20} \mathrm{O}_{9}\right) ; \quad{ }^{1} \mathrm{H}-\mathrm{NMR} \quad(600 \mathrm{MHz}$, DMSO- $\left.d_{6}\right) \delta: 13.1(s, 1-\mathrm{OH}), 7.88(m, \mathrm{H}-5), 7.86(m, \mathrm{H}-$ 6) $7.71(d$; $7.9 \mathrm{~Hz}, \mathrm{H}-7) 7.51$ (br s, H-4) 7.21 (br s, H-2) 5.20-3.10 (Glu), 2.44 (s, 3- $\left.\mathrm{CH}_{3}\right) ;{ }^{13} \mathrm{C}-\mathrm{NMR}(150 \mathrm{MHz}$, DMSO- $\left.d_{6}\right) \delta$ : 188.0 (C-9), 182.6 (C-10), 162.2 (C-1), 158.7 (C-8), 148.1 (C-3), 136.4 (C-6), 135.2 (C-11), 132.6 (C-14), 124.5 (C-2), 122.9 (C-7), 121.0 (C-5), 119.8 (C-4), 115.3 (C-12), 115.2 (C-13), 101.0 (C-1'), 77.8 (C-5'), 77.0 (C-3'), 73.7 (C-2'), 70.0 (C-4'), 61.1 (C-6'), 21.9 $\left(-\mathrm{CH}_{3}\right)$.

\section{Physcionin (7)}

Yellow powder; $\left(\mathrm{C}_{22} \mathrm{H}_{22} \mathrm{O}_{10}\right) ;{ }^{1} \mathrm{H}-\mathrm{NMR} \quad(600 \mathrm{MHz}$, DMSO- $\left.d_{6}\right) \delta: 12.8(s, 1-\mathrm{OH}), 7.50$ (br s, H-4), 7.37 (d, $2.3 \mathrm{~Hz}, \mathrm{H}-5) 7.19$ (d, $2.3 \mathrm{~Hz}, \mathrm{H}-7) 7.18$ (br s, H-2), 5.203.10 (Glu), $3.97\left(s,-\mathrm{OCH}_{3}\right), 2.42\left(s,-\mathrm{CH}_{3}\right) ;{ }^{13} \mathrm{C}-\mathrm{NMR}$ (150 MHz, DMSO- $d_{6}$ ) $\delta 186.9$ (C-9), 182.4 (C-10), 165.2 (C-6), 162.1 (C-1), 161.2 (C-8), 147.6 (C-3), 135.1 (C-11), 132.5 (C-14), 124.7 (C-2), 119.7 (C-4), 114.96 (C-13), 114.95 (C-12), 107.9 (C-7), 106.9 (C-5), 101.1 (C-1'), 77.9 (C-5'), 77.1 (C-3'), 73.8 (C-2'), 70.3 (C-4'), 61.3 (C$\left.6^{\prime}\right), 56.6\left(-\mathrm{OCH}_{3}\right) 21.8\left(-\mathrm{CH}_{3}\right)$.

\section{Antimicrobial activity}

Analysis of inhibitory parameters revealed variability in antimicrobial activity within extracts and isolated compounds, and within microbial strains tested (Table 1). Thus, all the three organic extracts exhibited activity in all the microorganisms tested, with MIC and MMC values varying between 32 and $256 \mu \mathrm{g} / \mathrm{mL}$. The highest activity observed with the crude extract $(\mathrm{MIC}=32 \mu \mathrm{g}$ / $\mathrm{mL}$ ) was found against $C$. neoformans, and particularly the EtOAc fraction against S. flexneri, S. aureus and $C$. albicans. This fraction was the most active with MIC values between 32 and $64 \mu \mathrm{g} / \mathrm{mL}$. Although in most cases the MMC values appeared to be double the MICs, the methanolic and acetate extracts were found to be fungicidal against $C$. neoformans at $32 \mu \mathrm{g} / \mathrm{mL}$ while at the same concentration the EtOAc fraction was bactericidal against $S$. flexneri.

With regards to the isolated compounds, their MMC were either equal to or two times higher than the corresponding MIC. The most active inhibited bacterial and fungal growth at a concentration of $8 \mu \mathrm{g} / \mathrm{mL}$, and in some cases their activity was comparable to that of the reference drug. At this concentration of $8 \mu \mathrm{g} / \mathrm{ml}$, the compounds 2 and $\mathbf{4}$ inhibited the growth of $C$. albicans and $C$. neoformans, and also exhibited a fungicidal activity against these strains. An inhibition of growth accompanied by microbicidal activity was noted with the compound 4 as well as the mixture $6+7$ against $C$. neoformans and $S$. aureus. However, these compounds displayed bactericidal activity against S. flexneri at $16 \mu \mathrm{g} /$ 
Table 1 Antimicrobial activity (MIC and MMC in $\mu \mathrm{g} / \mathrm{mL}$ ) of extracts and isolated compounds from R. abyssinicus as well as reference antimicrobial drugs

\begin{tabular}{|c|c|c|c|c|c|c|c|c|}
\hline Extracts/ Compounds & Inhibition parameters & $P$. aeruginosa & S. flexneri & S. aureus & MSSA01 & MRSA03 & C. albicans & C. neoformans \\
\hline \multirow[t]{3}{*}{$\mathrm{MeOH}$ extract } & MIC & 64 & 128 & 64 & 64 & 64 & 64 & 32 \\
\hline & MMC & 128 & 128 & 128 & 128 & 128 & 64 & 32 \\
\hline & MMC/MIC & 2 & 1 & 2 & 2 & 2 & 1 & 1 \\
\hline \multirow[t]{3}{*}{ EtOAc fraction } & MIC & 64 & 32 & 32 & 64 & 64 & 32 & 32 \\
\hline & MMC & 128 & 32 & 64 & 64 & 64 & 64 & 32 \\
\hline & MMC/MIC & 2 & 1 & 2 & 1 & 1 & 2 & 1 \\
\hline \multirow[t]{3}{*}{ n-BuOH fraction } & MIC & 128 & 128 & 128 & 256 & 256 & 64 & 32 \\
\hline & MMC & 256 & 256 & 128 & 256 & 256 & 64 & 64 \\
\hline & MMC/MIC & 2 & 2 & 1 & 1 & 1 & 1 & 2 \\
\hline \multirow[t]{3}{*}{1} & MIC & 64 & 32 & 32 & 64 & 64 & 64 & 32 \\
\hline & MMC & 128 & 32 & 64 & 64 & 128 & 64 & 32 \\
\hline & MMC/MIC & 2 & 1 & 2 & 1 & 2 & 1 & 1 \\
\hline \multirow[t]{3}{*}{2} & MIC & 8 & 8 & 8 & 16 & 16 & 8 & 8 \\
\hline & MMC & 16 & 16 & 8 & 32 & 32 & 8 & 8 \\
\hline & MMC/MIC & 2 & 2 & 1 & 2 & 2 & 1 & 1 \\
\hline \multirow[t]{3}{*}{3} & MIC & 128 & 128 & 256 & $>256$ & $>256$ & 128 & 64 \\
\hline & MMC & 256 & $>256$ & $>256$ & $>256$ & $>256$ & $>256$ & 128 \\
\hline & MMC/MIC & 2 & / & / & / & / & / & 2 \\
\hline \multirow[t]{3}{*}{4} & MIC & 16 & 8 & 8 & 32 & 32 & 8 & 8 \\
\hline & MMC & 16 & 16 & 8 & 32 & 32 & 8 & 8 \\
\hline & MMC/MIC & 1 & 2 & 1 & 1 & 1 & 1 & 1 \\
\hline \multirow[t]{3}{*}{5} & MIC & 32 & 32 & 32 & 128 & 128 & 16 & 16 \\
\hline & MMC & 64 & 32 & 32 & 256 & 256 & 32 & 32 \\
\hline & MMC/MIC & 2 & 1 & 1 & 2 & 2 & 2 & 2 \\
\hline \multirow[t]{3}{*}{$6+7$} & MIC & 16 & 8 & 8 & 16 & 16 & 16 & 8 \\
\hline & MMC & 16 & 16 & 8 & 16 & 32 & 16 & 8 \\
\hline & MMC/MIC & 1 & 2 & 1 & 1 & 2 & 1 & 1 \\
\hline \multirow[t]{3}{*}{$\operatorname{Ref}^{a}$} & MIC & 0.5 & 8 & 0.5 & 4 & 4 & 1 & 2 \\
\hline & MMC & 0.5 & 8 & 0.5 & 4 & 4 & 1 & 2 \\
\hline & MMC/MIC & 1 & 1 & 1 & 1 & 1 & 1 & 1 \\
\hline
\end{tabular}

I: not determined; MIC Minimum Inhibitory Concentration; MMC Minimum Microbicidal Concentration; ${ }^{\text {a }}$ fluconazole for yeasts and ciprofloxacin for bacteria

$\mathrm{mL}$, i.e. twice their MIC. Similar observations were noted on compound 2 against $P$. aeruginosa. All of the strains tested were less sensitive to the compound 3.

\section{Combined effect of the $\mathrm{MeOH}$ extract/compounds and antibiotics}

The results of the interaction study between the methanolic extract/compounds ( 2 and 4 ), and ciprofloxacin in bacteria or fluconazole in yeasts are presented in Table 2. We found that the effect of the association of the methanolic extract with this antibacterial and antifungal agents was synergistic in nature whatever the microorganism tested. Nevertheless, the association between compound 2 and ciprofloxacin exhibited an additive effect against
MSSA01 and MRSA03 strains. The interaction between compound $\mathbf{4}$ and fluconazole was also shown to be additive with respect to the yeasts $C$. albicans and $C$. neoformans. An additive effect was also observed against $C$. albicans when this compound was combined with ciprofloxacin.

\section{Mechanisms of antibacterial activity}

The study of the mechanism of action of the methanol extract/ compound $\mathbf{2}$ in comparison with the reference antibiotic, ciprofloxacin was carried out by measuring on the one hand the optical densities at 260 and $280 \mathrm{~nm}$ and on the other hand the appearance of reducing sugars in the bacterial culture suspensions, and finally by 
Table 2 Interactions of the methanol extract/compounds from R. abyssinicus and antibiotics against bacterial and yeast species

\begin{tabular}{|c|c|c|c|c|c|c|c|c|c|c|c|c|}
\hline \multirow[t]{2}{*}{ Microorganisms } & \multicolumn{4}{|c|}{$\mathrm{MeOH}$ extract } & \multicolumn{4}{|c|}{ Compound 2} & \multicolumn{4}{|c|}{ Compound 4} \\
\hline & FICA & FICEx & FIC & Interpretation & FICA & FIC2 & FIC & Interpretation & FICA & FIC5 & FIC & Interpretation \\
\hline P. aeruginosa & 0.25 & 0.125 & 0.37 & Synergistic & 0.125 & 0.125 & 0.25 & Synergistic & 0.25 & 0.125 & 0.25 & Synergistic \\
\hline S. flexneri & 0.125 & 0.125 & 0.25 & Synergistic & 0.031 & 0.25 & 0.281 & Synergistic & 0.0625 & 0.25 & 0.31 & Synergistic \\
\hline S. aureus & 0.25 & 0.125 & 0.37 & Synergistic & 0.25 & 0.125 & 0.375 & Synergistic & 0.5 & 0.125 & 0.625 & Additive \\
\hline MSSA01 & 0.125 & 0.0625 & 0.18 & Synergistic & 0.0625 & 0.5 & 0.5625 & Additive & 0.25 & 0.25 & 0.5 & Synergistic \\
\hline MRSAO3 & 0.125 & 0.125 & 025 & Synergistic & 0.0625 & 0.5 & 0.5625 & Additive & 0.25 & 0.125 & 0.375 & Synergistic \\
\hline C. albicans & 0.125 & 0.0625 & 0.18 & Synergistic & 0.0625 & 0.0625 & 0.125 & Synergistic & 0.25 & 0.5 & 0.75 & Additive \\
\hline C. neoformans & 0.0625 & 0.0625 & 0.125 & Synergistic & 0.0625 & 0.0625 & 0.125 & Synergistic & 0.25 & 0.5 & 0.75 & Additive \\
\hline
\end{tabular}

FICA MIC of antibiotic tested in combination/MIC of antibiotic tested alone; FICEx MIC of extract tested in combination/MIC of extract tested alone; FIC2 MIC of compound $\mathbf{2}$ tested in combination with antibiotic/ MIC of compound $\mathbf{2}$ tested alone; FIC4 MIC of compound $\mathbf{4}$ tested in combination with antibiotic/ MIC of compound $\mathbf{4}$ tested alone; FIC: MIC of antibiotic tested in combination/MIC of antibiotic tested alone + MIC of extract/compound tested in combination/MIC of extract/compound tested alone; antibiotics: ciprofloxacin for bacteria and fluconazole for yeasts

measuring the activity of the respiratory chain dehydrogenase enzyme activity. These results are illustrated in Figs. 2, 3 and 4, respectively.

\section{Effect on the cell membrane leakage}

It was noted that the methanolic extract and the compound 2 induced leakage of biological material absorbing at 260 and $280 \mathrm{~nm}$ by $P$. aeruginosa (Fig. 2a and b) and S. flexneri (Fig. 2c and d), at concentrations equal to or two times their MIC. However, this effect of the tested samples on membrane leakage was found to be concentration dependent in the presence of both microorganisms. In the presence of $P$. aeruginosa, compound 2 displayed higher leakage effect than the crude extract.

Effect on the sugar leakage of membrane from the bacteria The study of the appearance of reducing sugar also revealed that the latter increased in the bacterial culture suspensions as the concentration of the methanolic extract as well as that of the compound 2 tested increased from $1 / 2$ CMI to $2 \mathrm{MIC}$ through MIC (Fig. 3). The appearance of reducing sugar was also more important in the presence of the product $\mathbf{2}$ as compared to the $R$. abyssinicus extract.

\section{Effect on the respiratory chain dehydrogenase enzyme activity in the bacteria}

The effect of $\mathrm{MeOH}$ extract and compound 2 on respiratory chain dehydrogenase in $P$. aeruginosa and $S$. flexneri expressed as average TriPhenyl Formazan (TPF) formed is illustrated in Fig. 4. Generally, for a tested concentration of a compound and on a given microorganism, we observed an increase in TPF released over time. However, as the concentration of the agent tested increased, there was a significant decrease in the TPF formed for each incubation time. This reduction was more important against $S$. flexneri both for the crude extract and for the compound $\mathbf{2}$ tested.

\section{Antioxidant activity}

Regarding the antioxidant activity, the capacity of the extract or compounds to scavenge the DPPH radical was determined and expressed in $\mathrm{EC}_{50}$, followed by determination of the total antioxidant capacity expressed in Gallic acid equivalent (GEAC). From these results documented in Table 3, it was observed that compound 2 displayed a significant scavenging potential against the $\mathrm{DPPH}$ radical $\left(\mathrm{EC}_{50}=3.08 \pm 0.44 \mu \mathrm{g} / \mathrm{mL}\right)$, closed to that of the reference vitamin $C(1.81 \pm 0.19 \mu \mathrm{g} / \mathrm{mL})$. However, compounds $\mathbf{1}$ and $\mathbf{6}+7$ had an interesting scavenging power against the DPPH radical with $\mathrm{EC}_{50}$ values of $4.52 \pm 0.36 \mu \mathrm{g} / \mathrm{mL}$ and $7.63 \pm 1.27 \mu \mathrm{g} / \mathrm{mL}$, respectively compared to the $\mathrm{MeOH}(62.11 \pm 0.39 \mu \mathrm{g} / \mathrm{mL})$, EtOAc $(72.29 \pm 0.71 \mu \mathrm{g} / \mathrm{mL})$ and $n-\mathrm{BuOH}(76.54 \pm 0.78 \mu \mathrm{g} / \mathrm{mL})$ extracts.

In addition, compounds $\mathbf{1}$ and $\mathbf{2}$ displayed the highest total antioxidant capacity values of $106.03 \pm 0.87 \mu \mathrm{g} / \mathrm{mL}$ and $104.87 \pm 1.43 \mu \mathrm{g} / \mathrm{mL}$, respectively. They were successively followed by the mixture of compounds $6+7$, compound 5, compound 4, then the MeOH, EtOAc and $n$ $\mathrm{Bu}-\mathrm{OH}$ extracts with GEAC values of $83.38 \pm 0.22$, $81.09 \pm 0.93,79.54 \pm 1.26,73.23 \pm 0.61,58.44 \pm 0.38$ and $40.46 \pm 0.74 \mu \mathrm{g} / \mathrm{mL}$, respectively.

\section{Cytotoxic activity}

The cytotoxic activity of extracts and isolated compounds from $R$. abyssinicus was studied by assessing the haemolytic activity against red blood cells (RBCs) using Triton X-100 as a positive control. We observed $100 \%$ lysis with the positive control, as compared to the phosphate buffer saline (PBS) which showed no lysis of RBCs. Interestingly, none of the tested extracts and compounds showed a loss of membrane integrity as a result of cell lysis at concentrations up to $2048 \mu \mathrm{g} / \mathrm{mL}$ for the extracts and $256 \mu \mathrm{g} / \mathrm{mL}$ for the isolated compounds (results not shown). 


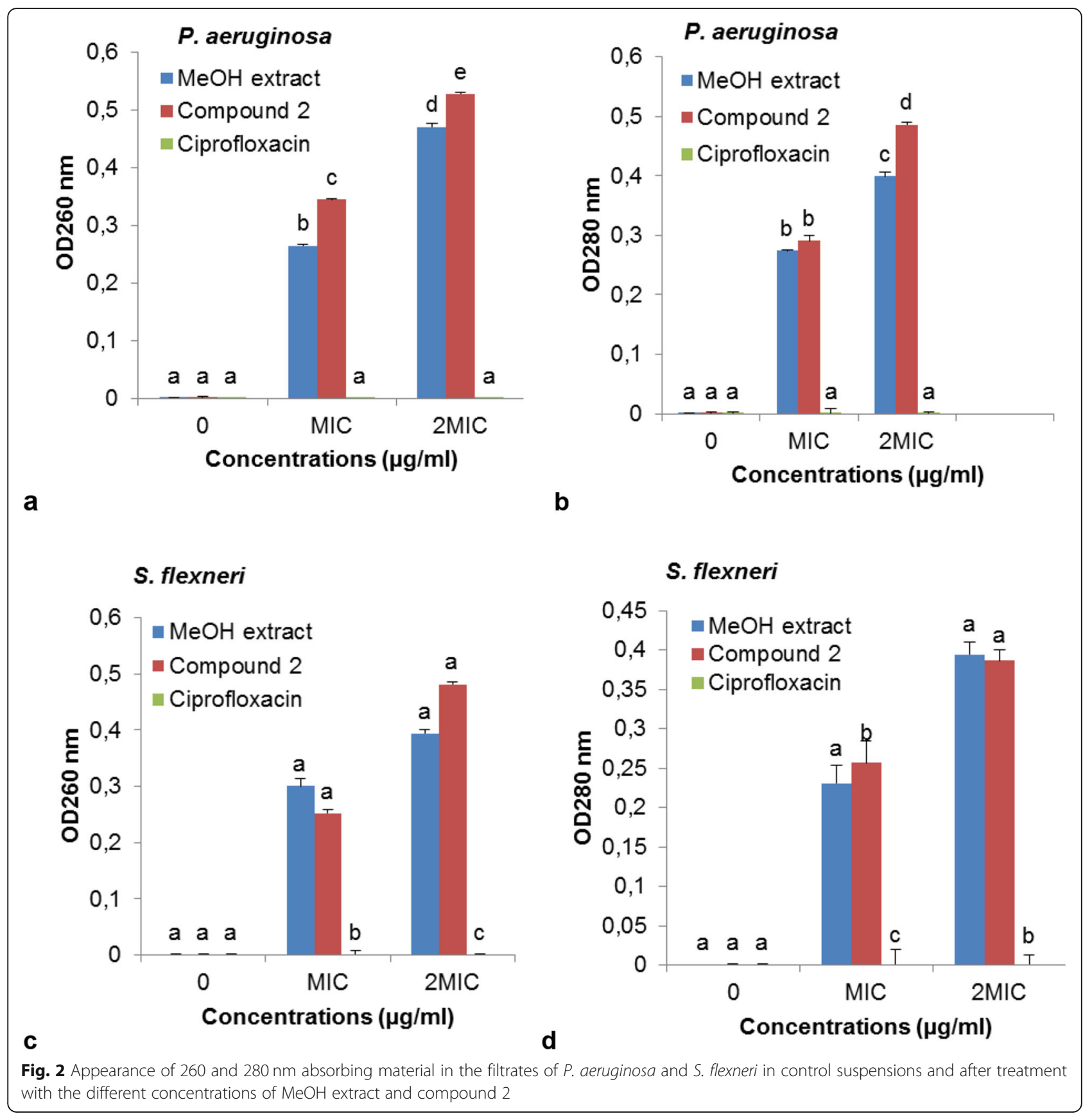

\section{Discussion}

The forthcome of resistant strains of bacteria and fungi against conventional antimicrobial drugs as well as side effects associated to antibiotherapy has increased the search for natural product as alternative ways to fight these organisms. Since earliest civilization, medicinal plants have been utilized by medical practitioners to treat various health related problems, and amongst these are bacterial and fungal infections [35]. Plant extracts and natural compounds are effective in the treatment of infectious diseases while at the same time alleviating many of the adverse effects associated with conventional antimicrobials [36]. This study assessed the antimicrobial and antioxidant activities of $R$. abyssinicus extracts and its isolated compounds. This plant is renowned for its multiple uses in herbal medicine to treat health issues involving oxidative stress, as well as bacterial and fungal infections.

A bio-guided fractionation of this plant was then performed to identify the potential agents endowed with antimicrobial and/or antioxidant activity. A total of five pure compounds ( $\mathbf{1}$ to $\mathbf{5}$ ) and one mixture of two 


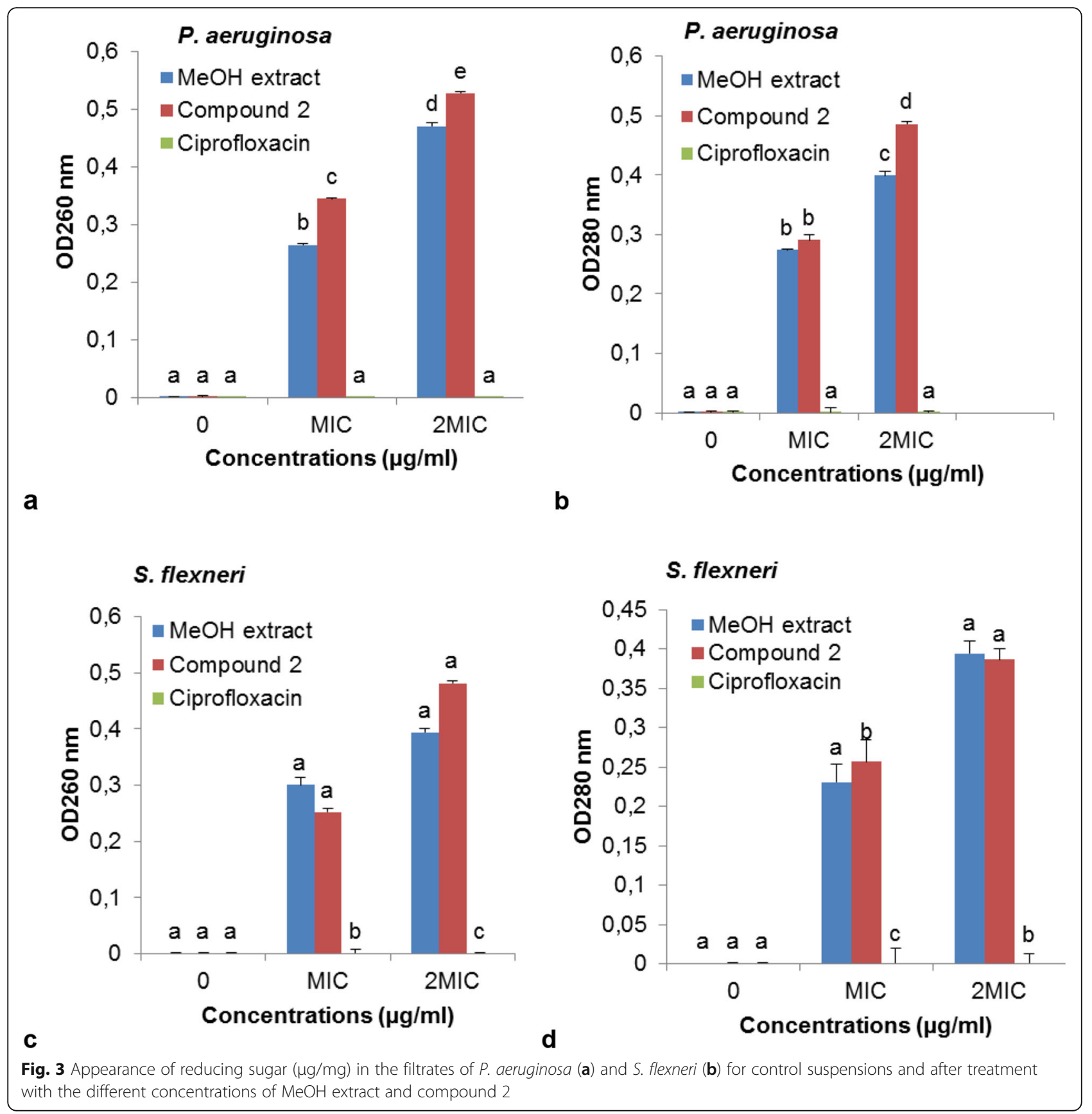

compounds (6 and 7) were isolated from EtOAc fraction of $R$. abyssinicus. Compound 1, identified as chrysophanol, was first reported from Rheum rhabarbarum, a herbaceous perennial plant belonging to the Polygonaceae family [37], and it has been found in various families, such as Polygonaceae, Rhamnaceae, Fabaceae, Liliaceae, Asphodelaceae, Buphorbiaceae, Meliaceae, Podocarpaceae, Picramniaceae, and Hemerocallidaceae [38, 39]. Compound 2, physcion, is a naturally occurring anthraquinone derivative, and a major bioactive ingredient in the traditional Chinese medicine Radix and
Rhizoma rhei [40]. It is a dihydroxyanthraquinone or 9, 10 -anthraquinone bearing hydroxy substituents at positions 1 and 8, a methoxy group at position 3, and a methyl group at position 6 . Compound 3 was identified as ergosta-6,22-diene-3,5,8-triol, a polyhydroxysterol that has been previously isolated from Lentinus edodes [23]. Compound 4, emodin, is an anthraquinone derivative that was first reported in Aspergillus wentii, a mycotoxin [41]. Compound 5 was identified as 6-hydroxyemodin (citreorosein), reported in the Rumex genus for the first time by Ertürk et al. [42]. Compound 6, chrysophanein, 

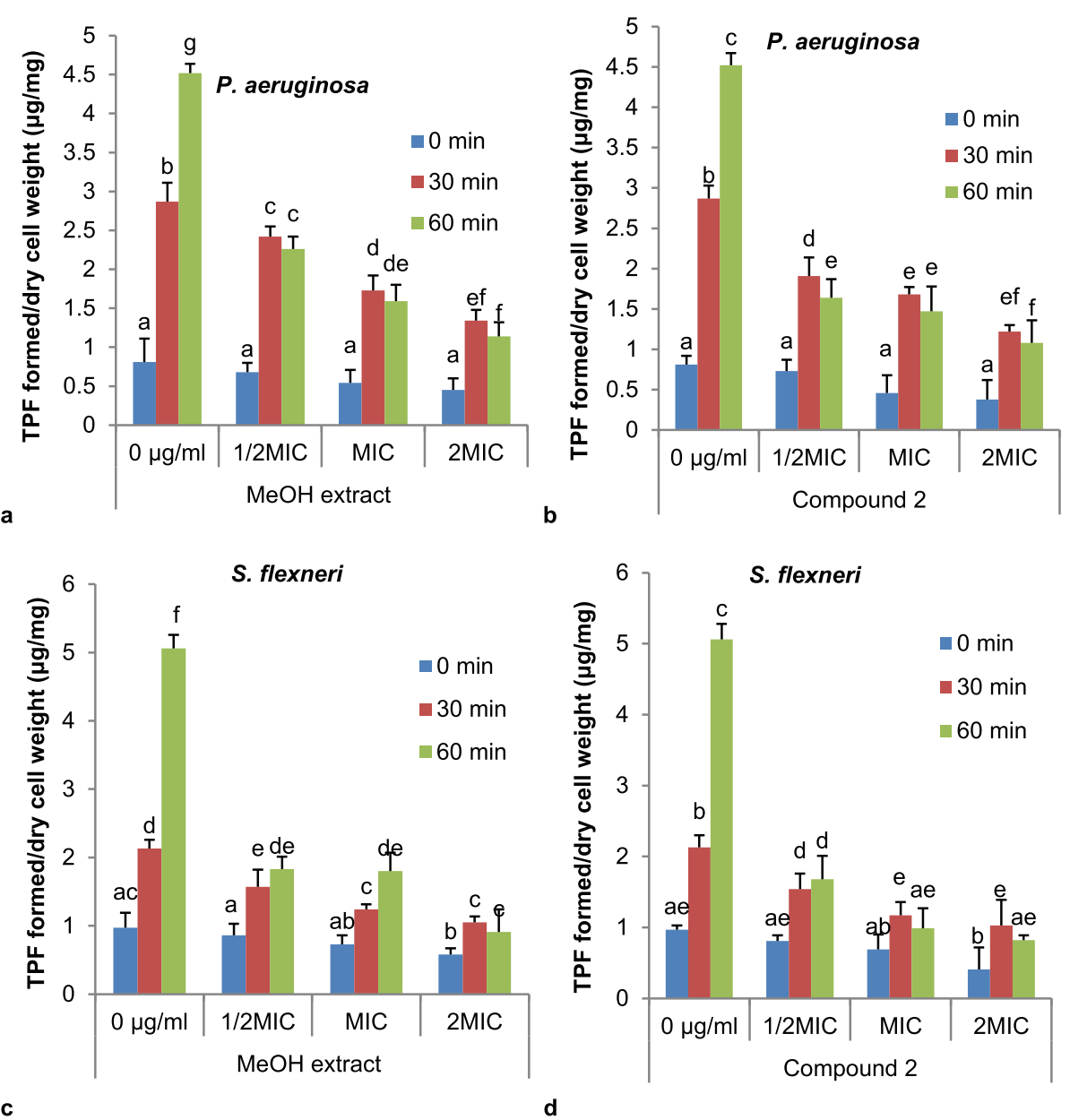

Fig. 4 Effect of $\mathrm{MeOH}$ extract and compound 2 on respiratory chain dehydrogenase in P. aeruginosa and S. flexneri. TPF: TriPhenyl Formazan

is a chrysophanol glycoside that has been previously identified from leaves and roots of Aloe hijazensis [43]. Finally compound 7 identified as physcionin, is distributed in root of nearly all Rheum species [44].
All the three organic extracts exhibited activities against all the tested microorganisms, with MIC and MMC values varying between 32 and $256 \mu \mathrm{g} / \mathrm{mL}$. Previous studies have reported the crude extract of $R$. abyssinicus to exhibit antibacterial $[15,16]$, anticancer [16],

Table 3 Antioxidant activities of extracts and some isolated compounds from $R$. abyssinicus

\begin{tabular}{lll}
\hline Extracts/compounds & DPPH free radical scavenging activity $\left(\mathrm{EC}_{\mathbf{5 0}, \boldsymbol{\mu} \mathbf{g} / \mathbf{m L})}\right.$ & Gallic acid equivalent antioxidant capacity $(\mathrm{GEAC}, \boldsymbol{\mu g} / \mathbf{m L})$ \\
\hline MeOH extract & $62.11 \pm 0.39^{\mathrm{a}}$ & $73.23 \pm 0.61^{\mathrm{a}}$ \\
EtOAC fraction & $72.29 \pm 0.71^{\mathrm{b}}$ & $58.44 \pm 0.38^{\mathrm{b}}$ \\
$n-\mathrm{BuOH}$ fraction & $76.54 \pm 0.78^{\mathrm{c}}$ & $40.46 \pm 0.74^{\mathrm{c}}$ \\
$\mathbf{1}$ & $4.52 \pm 0.36^{\mathrm{d}}$ & $104.87 \pm 1.43^{\mathrm{d}}$ \\
$\mathbf{2}$ & $3.08 \pm 0.44^{\mathrm{e}}$ & $106.03 \pm 0.87^{\mathrm{d}}$ \\
$\mathbf{4}$ & $10.69 \pm 0.51^{\mathrm{f}}$ & $79.54 \pm 1.26^{\mathrm{e}}$ \\
$\mathbf{5}$ & $9.88 \pm 0.62^{\mathrm{f}}$ & $81.09 \pm 0.93^{\mathrm{e}}$ \\
$\mathbf{6}+\mathbf{7}$ & $7.63 \pm 1.27^{\mathrm{g}}$ & $83.38 \pm 0.22^{\mathrm{f}}$ \\
Vitamin C & $1.81 \pm 0.19^{\mathrm{h}}$ & $/$ \\
\hline
\end{tabular}

$\mathrm{EC}_{50}$ : Equivalent concentrations of test samples scavenging $50 \%$ of DPPH radical. Data represent the mean \pm SD of three independent experiments carried out in triplicate. In the same column, values affected by different superscript letters (a-h) are significantly different according to one way ANOVA and Waller Duncan test; $\mathrm{p}<0.05$; /: not determined 
antiviral [15], anti-inflammatory [15, 17], antioxidant [18], wound healing [17], antimalarial [19], diuretic and analgesic [20] activities.

However, the highest activity ( $\mathrm{MIC}=32 \mu \mathrm{g} / \mathrm{mL}$ ) was found with the three extracts against $C$. neoformans, and particularly the EtOAc fraction against S. flexneri, S. aureus and C. albicans. This fraction was the most active with MIC values between 32 and $64 \mu \mathrm{g} / \mathrm{mL}$. However, although in most cases the MMC values appeared to be double the MICs, the $\mathrm{MeOH}$ extract and EtOAc fraction were found to be fungicidal against $C$. neoformans at $32 \mu \mathrm{g} / \mathrm{mL}$ while at the same concentration the ethyl acetate fraction was bactericidal against $S$. flexneri.

This study evaluated the antibacterial, antifungal and antioxidant activities of compounds isolated from $R$. abyssinicus. Most of these compounds were found to exhibit microbicidal effect with MMCs values that were either equal to or two times higher than the corresponding MICs. Compounds $\mathbf{2}$ and $\mathbf{4}$ inhibited the growth of $C$. albicans and C. neoformans at concentration of $8 \mu \mathrm{g} / \mathrm{mL}$, and also exhibited a fungicidal activity against these strains. Several studies have documented a variety of pharmacological properties of physcion including laxative, hepatoprotective, antineoplastic, antiinflammatory and anti-microbial activities [40, 45]. Compound 4, emodin, has also been shown to display antibacterial, antifungal, antiparasitic, antioxidant, and antiviral activities [46]. The mixture of $6+7$ also displayed considerable antimicrobial activity with bactericidal effect against $S$. flexneri at $16 \mu \mathrm{g} / \mathrm{mL}$ while compound 3 was inactive against most of the tested strains.

The effect of the association of the $\mathrm{MeOH}$ extract with ciprofloxacin and fluconazole was synergistic in nature irrespective of the microorganism tested. Compound $\mathbf{2}$ associated to ciprofloxacin exhibited synergistic effect except on MSSA01 and MRSA03 strains. A synergistic effect was also observed when compound 4 was combined with ciprofloxacin against MSSA01 and MRSA03 strains. These results indicate an increased susceptibility against the test antibiotics. Synergistic combinations have been shown to render the microorganisms extremely susceptible to concentrations of both antimicrobial agents which can be easily obtained or exceeded in the serum after administration of usual doses [47], suggesting the need of exploring the combination potential of $\mathrm{MeOH}$ extract, compounds $\mathbf{2}$ and $\mathbf{4}$ with reference antimicrobial drugs, to combat resistant strains. To the best of our knowledge, this is the first report of test samples and ciprofloxacin / fluconazole association against MDR strains.

This study also shows that $\mathrm{MeOH}$ extract and compound 2 induced leakage of biological material absorbing at 260 and $280 \mathrm{~nm}$, probably nucleic acids and proteins derivatives by $P$. aeruginosa and $S$. flexneri, at concentrations equal to or two times their MIC. These observations suggest the contribution of compound $\mathbf{2}$ and $\mathrm{MeOH}$ extract to the alteration of microbial membrane, and the resulting leakage of intracellular material may lead to microbial death, justifying their microbicidal effect. Similar mechanisms of bacterial death have been reported in earlier studies [28]. The ability of the $\mathrm{MeOH}$ extract and compund $\mathbf{2}$ to alter bacterial cell membrane was further demonstrated by increased reducing sugars in the culture suspension as the concentration of both the tested $\mathrm{MeOH}$ extract and compound 2 raised from $1 / 2$ MIC to 2 MIC through MIC. The appearance of reducing sugar was also more important in the presence of the compound $\mathbf{2}$ as compared to the $R$. abyssinicus extract. These observations have been documented with terpenoids from the leaves of Tridax procumbens Linn. against E. coli [48]. In this study, the $\mathrm{MeOH}$ extract of R. abyssinicus and compound $\mathbf{2}$ were also found to inhibit respiratory chain enzyme dehydrogenase of $P$. aeruginosa and S. flexneri. The decrease in the activity of this enzyme, may contribute to the inhibition of microbial growth and probably lead to death. Candidly, the inhibition of dehydrogenase activity in pathogenic bacteria is indicative of a strong antimicrobial activity since inhibition of oxido-reductases such as dehydrognases, affects respiration of the microbe.

The study of the antioxydant properties of $R$. abyssinicus extract and isolated compounds revealed the potential of the extract/isolated compounds to scavenge the DPPH radical, with compound 2 identified with highest scavenging power against the DPPH radical. Compounds 1, 4, 5 and $6+7$ also displayed interesting scavenging power against the DPPH radical compared to the $\mathrm{MeOH}, \mathrm{EtOAc}$ and $n-\mathrm{BuOH}$ extracts. Overall, compounds 1 and 2 had the highest total antioxidant capacity whereas the EtOAc and $n-\mathrm{BuOH}$ extracts were the least active. These observations suggest that fractionation enhanced the antioxidant activities of compounds 1, 2, 4, 5 and $\mathbf{6}+7$ and diluted those of the EtOAc and $n$ - $\mathrm{BuOH}$ extracts. Therefore, the presence of such compounds could be partially responsible for the antioxidant activity (AOA) found in these plant extracts; the AOA depends on the method used, reinforcing the concept that this plant extracts contain several antioxidant compounds that act in different manners. The antimicrobial and antioxidant activities of compounds $\mathbf{1}, \mathbf{2}$ and $\mathbf{4}$ are in accordance with the previous studies $[19,29,40,46$, 49]. However, this is the first report on the antibacterial, antifungal and antioxidant activities of compounds 3, 5-7 against free radicals and pathogenic bacteria and fungi. The antioxidant activities of these compounds coupled to their antimicrobial properties, may offer a therapeutic option for the treatment of infectious diseases while 
simultaneously mitigating many of the side effects that are often associated with conventional antimicrobials [36].

\section{Conclusions}

$R$. abyssinicus is a potential source of antibacterial, antifungal and antioxidant agents. Their mechanism of antibacterial activity is due to disruption of the cytoplasmic membrane and inhibition of the microbial respiratory chain dehydrogenase enzyme activity. Interestingly, none of the tested extracts/compounds showed cytotoxic activity against normal cells; highlighting their suitability and selectivity toward pathogenic bacteria and yeasts. The $\mathrm{MeOH}$ extract and compounds $\mathbf{2}$ and $\mathbf{4}$ displayed synergistic effect with the ciprofloxacin and fluconazole. The observed activity of the isolated compounds against bacteria and fungi including MDR strains deserves further exploration.

\begin{abstract}
Abbreviations
${ }^{13} \mathrm{C}$-NMR: Carbon Thirteen Nuclear Magnetic Resonance; ${ }^{1} \mathrm{H}$-NMR: Proton Nuclear Magnetic Resonance; 2D NMR: Two-dimension Nuclear Magnetic Resonance; ATCC: American Type Culture Collection; CC: Column Chromatography; COSY: Correlation Spectroscopy; DMSO: Dimethylsulfoxide; EtOAc: Ethyl acetate; HMBC: Heteronuclear Multiple Bond Connectivities; HNC: Herbier National du Cameroun; HR-El-MS: High Resolution Electron Impact Mass Spectrometry; HR-TOFESIMS: High-Resolution Time of Flight Electrospray lonization Mass Spectrometry; HSQC: The Heteronuclear Single Quantum Coherence; IR: Infra-red; MDR: Multi-Drug-Resistant; MeOH: Methanol; MHA: Mueller Hinton agar; MHB: Mueller Hinton broth; MIC: Minimum inhibitory concentration; MMC: Minimum Microbicidal Concentration; NA: Nutrient agar; n-BuOH: n-Butanol; NMR: Nuclear Magnetic Resonance; Rf: Retention factor; TLC: Thin Layer Chromatography; TMS: Tetramethylsilane; TOF-ESIMS: Time of Flight Electrospray lonization Mass Spectrometry; UV: Ultra-violet
\end{abstract}

\section{Supplementary Information}

The online version contains supplementary material available at https://doi. org/10.1186/s12906-021-03325-y.

Additional file 1 Scheme 1 Protocol for extraction and purification of the EtOAc fraction of Rumex abyssinicus.

Additional file 2 Figure S1: ${ }^{1} \mathrm{H}-\mathrm{NMR}$ Spectrum of compound 1. Figure S2: ${ }^{13}$ C-NMR Spectrum of compound 1. Figure S3: HSQC Spectrum of compound 1. Figure S4: ${ }^{1} \mathrm{H}-{ }^{1} \mathrm{HCOSY}$ Spectrum of compound 1. Figure S5: HMBC Spectrum of compound 1. Figure S6: ${ }^{1} \mathrm{H}-\mathrm{NMR}$ Spectrum of compound 2. Figure S7: ${ }^{13} \mathrm{C}-\mathrm{NMR}$ Spectrum of compound 2. Figure S8: HSQC Spectrum of compound 2. Figure S9: COSY Spectrum of compound 2. Figure S10: $\mathrm{HMBC}$ Spectrum of compound 2. Figure S11: ${ }^{1} \mathrm{H}$-NMR Spectrum of compound 3. Figure S12: ${ }^{13} \mathrm{C}-\mathrm{NMR}$ Spectrum of compound 3. Figure S13: HSQC Spectrum of compound 3. Figure S14: ${ }^{1} \mathrm{H}-{ }^{1} \mathrm{H}$ COSY Spectrum of compound 3. Figure S15: HMBC Spectrum of compound 3. Figure S16: ${ }^{1} \mathrm{H}-\mathrm{NMR}$ Spectrum of compound 4. Figure S17: ${ }^{13} \mathrm{C}-\mathrm{NMR}$ Spectrum of compound 4. Figure S18: HSQC Spectrum of compound 4. Figure S19: ${ }^{1} \mathrm{H}-{ }^{1} \mathrm{HCOSY}$ Spectrum of compound 4. Figure S20: $H M B C$ Spectrum of compound 4. Figure S21: ${ }^{1} H-N M R$ Spectrum of compound 5. Figure S22: ${ }^{13} \mathrm{C}-\mathrm{NMR}$ Spectrum of compound 5. Figure S33: HSQC Spectrum of compound 5. Figure S24: ${ }^{1} \mathrm{H}-{ }^{1} \mathrm{H}$ COSY Spectrum of compound 5. Figure S25: HMBC Spectrum of compound 5. Figure S26: ${ }^{1} \mathrm{H}-\mathrm{NMR}$ Spectrum of compounds 6 and 7 . Figure S27: ${ }^{13} \mathrm{C}-\mathrm{NMR}$ Spectrum of compounds 6 and 7. Figure S28: HSQC Spectrum of compounds 6 and 7. Figure S29: ${ }^{1} \mathrm{H}-{ }^{1} \mathrm{HCOSY}$ Spectrum of compounds 6 and 7. Figure S30: HMBC Spectrum of compounds 6 and 7 .

\section{Acknowledgements}

The authors are grateful to the University of Dschang for financing some consumables used in this work, to the "Service Commun d'Analyses" and "Groupe Chimie des Substances Naturelles", to the "Institut de Chimie Moléculaire de Reims" for the spectroscopic and spectrometric analysis on the ESIMS and NMR equipement of the PIAnet Platform. The EU-programme FEDER to the PIAneT CPER project is gratefully acknowledged.

\section{Authors' contributions}

ICK, LDTF, AJN, CDJN and MDD contributed to the data collection and analysis. JDT designated the study, did the biological assays and helped in manuscript writing and editing. JDT, LVN and DN supervised and revised the manuscript critically for important intellectual content. All authors read and approved the final manuscript.

\section{Funding}

The authors had no funding for this work.

\section{Availability of data and materials}

The datasets used and analyzed during the current study are available from the corresponding author.

\section{Declarations}

Ethics approval and consent to participate

All the procedures and protocols involving animals and their care were followed in conformity with the institutional guidelines and approved by the Cameroon National Ethical Committee (Reg. No. FWA-IRB00001954) and in compliance with the ARRIVE guidelines.

\section{Consent for publication}

Not applicable.

\section{Competing interests}

The authors declare that they have no competing interests.

\section{Author details}

'Department of Biochemistry, Research Unit of Microbiology and Antimicrobial Substances, Faculty of Science, University of Dschang, P.O. Box 67, Dschang, Cameroon. '2Department of Chemistry, Research Unit of Applied and Environmental Chemistry, Faculty of Science, University of Dschang, P.O. Box 67, Dschang, Cameroon. ${ }^{3}$ Department of Biomedical Science, Faculty of Health Sciences, University of Buea, P.O. Box 12, Buea, Cameroon. ${ }^{4}$ Groupe Isolement et Structure, Institut de Chimie Moléculaire de Reims (ICMR), CNRS UMR 7312, Bat. 18 B.P. 1039, 51687 Reims Cedex 2, France.

Received: 22 January 2021 Accepted: 14 May 2021

Published online: 05 June 2021

\section{References}

1. Dewal MB, Wani AS, Vidaillac C, Oupický D, Rybak MJ, Firestine SM. Thieno [2,3-d] pyrimidinedione derivatives as antibacterial agents. Eur J Med Chem. 2012;51:145-53. https://doi.org/10.1016/j.ejmech.2012.02.035.

2. Nkomo LP. In vitro bioactivity of crude extracts of Lippia javanica on clinical isolates of Helicobacter pylori: Preliminary phytochemical screening. University of Fort Hare. Master' Thesis, University of Fort Hare, Faculty of Science \& Agriculture; 2010. p. 97.

3. Rojas J, Buitrago A. Essential oils and their products as antimicrobial agents: Progress and prospects. Chapter 13, 26p. In: Duarte MCT, Rai M, editors. Therapeutic Medicinal Plants From Lab to Mark; 2015.

4. Kalghatgi S, Spina CS, Costello JC, Liesa M, Morones-Ramirez JR, Slomovic S, et al. Bactericidal antibiotics induce mitochondrial dysfunction and oxidative damage in Mammalian cells. Sci Transl Med. 2013;5(192):192ra85.

5. Chanda S, Kaneria M, Nair R. Antibacterial activity of Psoralea corylifolia L. seed and aerial parts with various extraction methods. Res J Microbiol. 2011; 6(2):124.

6. Adeshina GO, Onaolapo JA, Ehinmidu JO, Odama LE. Phytochemical and antimicrobial studies of the ethyl acetate extract of Alchornea cordifolia leaf found in Abuja, Nigeria. J Med Plants Res. 2010;4(8):649-58.

7. Joubouhi C, Tamokou J-D-D, Ngnokam D, Voutquenne-Nazabadioko L, Kuiate J-R. Iridoids from Canthium subcordatum iso-butanol fraction with 
potent biological activities. BMC Compl Altern Med. 2017;17(1):17. https:// doi.org/10.1186/s12906-016-1536-8.

8. Nzogong RT, Ndjateu FST, Ekom SE, Fosso J-AM, Awouafack MD, Tene M, et al. Antimicrobial and antioxidant activities of triterpenoid and phenolic derivatives from two Cameroonian Melastomataceae plants: Dissotis senegambiensis and Amphiblemma monticola. BMC Compl Altern Med. 2018; 18(1):159. https://doi.org/10.1186/s12906-018-2229-2.

9. Davidson PM, Branen AL. Food antimicrobials - an introduction. In Davidson PM, Sofos JN, Branen AL (Eds.), antimicrobial in food (3rd ed.), Pp 1-10. New York, NY: CRC Press; 2005.

10. Sieniawska E, Swatko-Ossor M, Sawicki R, Skalicka-Woźniak K, Ginalska G. Natural terpenes influence the activity of antibiotics against isolated Mycobacterium tuberculosis. Med Princ Pract. 2017;26(2):108-12. https://doi. org/10.1159/000454680.

11. Tagousop CN, Tamokou J-D-D, Kengne IC, Ngnokam D, VoutquenneNazabadioko L. Antimicrobial activities of saponins from Melanthera elliptica and their synergistic effects with antibiotics against pathogenic phenotypes. Chem Cent J. 2018;12(1):97. https://doi.org/10.1186/s13065018-0466-6.

12. Ahmad I, Aqil F. In vitro efficacy of bioactive extracts of 15 medicinal plants against ESBL-producing multidrug-resistant enteric bacteria. Microbiol Res. 2007;162(3):264-75. https://doi.org/10.1016/j.micres.2006.06.010.

13. Rao K, Ch S, David Banji HS, Mahesh V. A study on the nutraceuticals from the genus Rumex. Hygeia J D Med. 2011;3(1):76-88.

14. Ken F (2019) Useful tropical plants database [online]. Available: http://tropical. theferns.info/viewtropical.php?id=Rumex+abyssinicus [Accessed 29-12-2019.

15. Getie M, Gebre-Mariam T, Rietz R, Höhne C, Huschka C, Schmidtke M, et al. Evaluation of the anti-microbial and anti-inflammatory activities of the medicinal plants Dodonaea viscosa, Rumex nervosus and Rumex abyssinicus. Fitoterapia. 2003; 74(1-2):139-43. https//doi.org/10.1016/S0367-326X(02)00315-5.

16. Tamokou J-D-D, Chouna JR, Fischer-Fodor E, Chereches G, Barbos O, Damian G, et al. Anticancer and antimicrobial activities of some antioxidantrich Cameroonian medicinal plants. PLoS One. 2013;8(2):e55880. https://doi. org/10.1371/journal.pone.0055880.

17. Mulisa E, Asres K, Engidawork E. Evaluation of wound healing and antiinflammatory activity of the rhizomes of Rumex abyssinicus J.(Polygonaceae) in mice. BMC Compl Altern Med. 2015;15(1):341.

18. Mohammed SA, Panda RC, Madhan B, Demessie BA. Extraction of bio-active compounds from Ethiopian plant material Rumex abyssinicus (mekmeko) root-a study on kinetics, optimization, antioxidant and antibacterial activity. J Taiwan Inst Chem Eng. 2017;75:228-39. https://doi.org/10.1016/j. jtice.2017.03.004

19. Muganga R, Angenot L, Tits M, Frederich M. Antiplasmodial and cytotoxic activities of Rwandan medicinal plants used in the treatment of malaria. J Ethnopharmacol. 2010;128(1):52-7. https://doi.org/10.1016/j.jep.2009.12.023.

20. Mekonnen T, Urga K, Engidawork E. Evaluation of the diuretic and analgesic activities of the rhizomes of Rumex abyssinicus Jaca in mice. J Ethnopharmacol. 2010;127(2):433-9. https://doi.org/10.1016/j.jep.2009.10.020.

21. Guo S, Feng B, Zhu R, Ma J, Wang W. Preparative isolation of three anthraquinones from Rumex japonicus by high-speed counter-current chromatography. Molecules. 2011;16(2):1201-10. https://doi.org/10.3390/molecules16021201.

22. Basu S, Ghosh A, Hazra B. Evaluation of the antibacterial activity of Ventilago madraspatana Gaertn., Rubia cordifolia Linn. And Lantana camara Linn.: isolation of emodin and physcion as active antibacterial agents. Phytother Res. 2005;19(10):888-94. https://doi.org/10.1002/ptr.1752.

23. Rivera A, Benavides OL, Rios-Motta J. (22E)-Ergosta-6,22-diene-3ß,5a,8a-triol: a new polyhydroxysterol isolated from Lentinus edodes (shiitake). Nat Prod Res. 2009;23(3):293-300. https://doi.org/10.1080/14786410802038671.

24. Zhang C, Wang X, Zhang X, Zhang Y, Xiao H, Liang X. Bioassay-guided separation of citreorosein and other oestrogenic compounds from Polygonum cuspidatum. Phytother Res. 2009;23(5):740-1. https://doi.org/10.1002/ptr.2619.

25. Kubo I, Murai Y, Soediro I, Soetarno S, Sastrodihardjo S. Cytotoxic anthraquinones from Rheum pulmatum. Phytochemistry. 1992;31(3):1063-5. https://doi.org/10.1016/0031-9422(92)80078-S.

26. Tamokou J-D-D, Tala MF, Wabo HK, Kuiate JR, Tane P. Antimicrobial activities of methanol extract and compounds from stem bark of Vismia rubescens. J Ethnopharmacol. 2009;124(3):571-5. https://doi.org/10.1016/j.jep.2009.04.062.

27. Climo MW, Patron RL, Archer GL. Combinations of vancomycin and $\beta$ lactams are synergistic against Staphylococcus with reduced susceptibilities to vancomycin. Antimicrob Agents Chemother. 1999:43(7):1747-53. https:// doi.org/10.1128/AAC.43.7.1747.
28. Karsha PV, Lakshmi OB. Antibacterial activity of black pepper (Piper nigrum Linn.) with special reference to its mode of action on bacteria. Indian J Nat Prod Resour. 2010;1(2):213-5.

29. Sathya-Bama S, Jayasurya Kingsley S, Sankaranarayanan S, Bama P. Antibacterial activity of different phytochemical extracts from the leaves of T. procumbens Linn.: identification and mode of action of the terpenoid compound as antibacterial. Int J Pharm Pharm Sci. 2012;4(1):557-64.

30. Kim K-J, Sung WS, Suh BK, Moon S-K, Choi J-S, Kim JG, et al. Antifungal activity and mode of action of silver nano-particles on Candida albicans. Biometals. 2009;22(2):235-42. https://doi.org/10.1007/s10534-008-9159-2.

31. Rice-Evans C, Miller NJ. Total antioxidant status in plasma and body fluids. Methods Enzymol. 1994;234:279-93. https:/doi.org/10.1016/0076-6879(94)34095-1.

32. Mot AC, Pârvu M, Damian G, Irimie FD, Darula Z, Medzihradszky KF, et al. "Yellow" laccase with "blue" spectroscopic features, from Sclerotinia sclerotiorum. Process Biochem. 2012;47(6):968-75. https://doi.org/10.1016/j. procbio.2012.03.006

33. Djouossi MG, Tamokou J-D-D, Ngnokam D, Kuiate J-R, Tapondjou LA, Harakat $\mathrm{D}$, et al. Antimicrobial and antioxidant flavonoids from the leaves of Oncoba spinosa Forssk. (Salicaceae). BMC Compl Altern Med. 2015;15(1):134.

34. Situ H, Bobek LA. In vitro assessment of antifungal therapeutic potential of salivary histatin-5 two variants of histatin-5 and salivary Mucin (MUC7) domain 1. Antimicrob Agents Chemother. 2000;44(6):1485-93. https://doi. org/10.1128/AAC.44.6.1485-1493.2000.

35. Tamokou J-D-D, Kuiate JR, Gatsing D, Efouet AP, Njouendou AJ. Antidermatophytic and toxicological evaluations of dichloromethanemethanol extract, fractions and compounds isolated from Coula edulis. Iran J Med Sci. 2011;36(2):111-21.

36. Iwu M, Duncan AR, Okunji CO. New Antimicrobials of Plant Origin. Pp. 457462. In: Janick J, editor. Perspectives on new crops and new uses. Alexandria: ASHS Press; 1999.

37. Tutin F, Clewer HWB. XCIX.-the constituents of rhubarb. J Chem Soc Trans. 1911;99(0):946-67. https://doi.org/10.1039/CT9119900946.

38. Kuo Y-H, Lee P-H, Wein Y-S. Four new compounds from the seeds of Cassia fistula. J Nat Prod. 2002;65(8):1165-7. https://doi.org/10.1021/np020003k.

39. Panichayupakaranant P, Sakunpak A, Sakunphueak A. Quantitative HPLC determination and extraction of anthraquinones in Senna alata leaves. J Chromatogr Sci. 2009;47(3):197-200. https://doi.org/10.1093/chromsci/47.3.197.

40. Agarwal S, Singh SS, Verma S, Kumar S. Antifungal activity of anthraquinone derivatives from Rheum emodi. J Ethnopharmacol. 2000;72(1-2):43-6. https://doi.org/10.1016/S0378-8741(00)00195-1.

41. Wells JM, Cole RJ, Kirksey JW. Emodin, a toxic metabolite of Aspergillus wentii isolated from weevil-damaged chestnuts. Appl Microbiol. 1975;30(1): 26-8. https://doi.org/10.1128/AM.30.1.26-28.1975.

42. Ertürk S, Özbas M, Imre S. Anthraquinone pigments from Rumex cristatus. ACTA Pharm Sci. 2001;43(1):21-2.

43. Abd-Alla HI, Shaaban M, Shaaban KA, Abu-Gabal NS, Shalaby NM, Laatsch H. New bioactive compounds from Aloe hijazensis. Nat Prod Res. 2009;23(11): 1035-49. https://doi.org/10.1080/14786410802242851.

44. He J, Wang L, Guo H, Zhao H, Sun J. Chemistry, pharmacology and processing method of rhubarb (Rheum species): a review. J Food Bioactives. 2019:8:42-50.

45. Pang M-J, Yang Z, Zhang X-L, Liu Z-F, Fan J, Zhang H-Y. Physcion, a naturally occurring anthraquinone derivative, induces apoptosis and autophagy in human nasopharyngeal carcinoma. Acta Pharmacol Sin. 2016; 37(12):1623-40. https://doi.org/10.1038/aps.2016.98.

46. Izhaki I. Emodin - a secondary metabolite with multiple ecological functions in higher plants. New Phytol. 2002;155(2):205-17. https://doi.org/1 0.1046/j.1469-8137.2002.00459.x.

47. Klastersky J, Cappel R, Daneau D. Clinical significance of in vtro synergism between antibiotics in gram-negative infections. Antimicrob Agents Chemother. 1972;2(6):470-5. https://doi.org/10.1128/AAC.2.6.470.

48. Bama SS, Kingsley SJ, Anan S, Bama P. Antibacterial activity of different phytochemical extracts from the leaves of T. procumbens: identification and mode of action of the terpeniod compounds as antibacterials. Int J Pharm Pharm Sci. 2012;4(1):557-64.

49. Prateeksha, Yusuf MA, Singh BN, Sudheer S, Kharwar RN, Siddiqui S, et al. Chrysophanol: A natural anthraquinone with multifaceted biotherapeutic potential. Biomolecules 2019;9:68, 2, DOl: https://doi.org/10.3390/biom9020068.

\section{Publisher's Note}

Springer Nature remains neutral with regard to jurisdictional claims in published maps and institutional affiliations. 